\title{
Perancangan Data Warehouse Untuk Informasi Strategi Studi Kasus Penerimaan Siswa Baru STIE Binaniaga Bogor
}

\author{
Rahmat Tri Yunandar ${ }^{1}$, Amir ${ }^{2}$, Khairul Rizal ${ }^{3}$ \\ ${ }^{123}$ Sistem Informasi Fakultas Teknologi Informasi \\ Universitas Bina Sarana Informatika \\ ${ }^{1}$ rahmat.rtr@bsi.ac.id, \\ 2amir.amr@bsi.ac.id, \\ ${ }^{3}$ khairul.krl@bsi.ac.id

\begin{tabular}{ccc}
\hline Diterima & Direvisi & Disetujui \\
$12-11-2019$ & $09-01-2020$ & $02-02-2020$ \\
\hline
\end{tabular}

\begin{abstract}
Abstrak - Institusi pendidikan perlu memiliki pengetahuan yang lebih, dalam mengevaluasi, merancang dan mengambil keputusan.Dimana dari pengetahun tersebut bisa didapat dari data kegiatan operasional yang tersimpan didalam database institusi pendidikan ke dalam data warehose, sehingga dapat digunakan sebagai pendukung dalam proses pengambilan keputusan. Peran data warehouse sangatlah besar dalam penyediaan strategi informasi yang bisa digunakan untuk memenuhi kebutuhan pihak manajemen dalam konteks bisnis. Penelitian ini mengkaji pengembangan data warehouse untuk data penerimaan mahasiswa baru pada STIE Binaniaga Bogor, yang mana dapat menggali informasi-informasi penting yang dapat membantu mengambilan keputusan strategi dalam menunjang kegiatan promosi di STIE Binaniaga Bogor. Tujuan akhir dari penelitian ini adalah untuk menghasilkan rancangan data warehouse yang dapat mendukung kebutuhan pihak manajemen dalam mengambil keputusan dengan cara memberikan informasi yang strategi tentang penerimaan mahasiswa baru, yang menghasilkan ringkasan informasi yang akurat dan berguna sebagai masukan untuk menentukan strategi dalam melakukan promosi.
\end{abstract}

Kata Kunci: Data Warehouse, Informasi Strategi, Penerimaan Mahasiswa Baru.

Abstract - As an Educational institutions need to have more knowledge, in evaluating, designing and making decisions. Where from such knowledge can be obtained from the data stored in the operational activities of educational institutions databases into the data warehose, so it can be used as a support in the decision making process. Data Warehouse has a major role in the provision of strategic information that can be used to meet the needs of management in a business context. This study examines the development of the data warehouse to the data of new admissions to the STIE Binaniaga Bogor, which can dig up important information that can help retrieval strategic decision to support promotional activities at the STIE Binaniaga Bogor. The final goal of this study was to produce a design of a data warehouse that can support the needs of management in making decisions by providing strategic information on new admissions, which produces a summary of information that is accurate and useful as input to determine strategies for promotion.

Keywords: Data Warehouse, Strategic Information, New Admissions.

\section{PENDAHULUAN}

Kemajuan teknologi disertai mobilitas kerja yang tinggi memberikan persaingan ketat dalam dunia usaha saat ini, sehingga pihak menejemen harus bisa mengimbangi dengan kecepatan dan ketepatan dalam proses pengambilan keputusan strategi. Informasi menjadi salah satu halyangsangatpenting,terutama informasi yang terpercaya sangatlah dibutuhkan dalam mengambil keputusan yang cepat dan akurat untuk mencapai tujuan bisnis yang telah ditetapkan. Dan Selain itu informasi yang diberikan juga harus dapat memiliki korelasi dan kontinuitas dengan informasi sebelumnya dimasa yang lalu, sehingga membantupihak manajemen dalam melihat perubahan perkembangan bisnisnya,serta dapat memperkirakanatau memprediksikankan kejadian dimasa yang akan datang untuk merumuskan keputusan strategi bisnis yang akan diambil.

Penerimaan mahasiswa baru (PMB) pada STIE Binaniaga Bogor sudah dilakukan secara Online 
Internet, dengan menggunakan website penerimaan mahasiswa barunya sejak tahun 2011 sampai saatini. Namun informasi yang dihasilkan berdasarkan pengolahan data operasional yang ada masih berupa laporan rutin. Hal ini menyebabkan pihak manajemen merasabelum memiliki laporan yang lebih ringkas dan belummelihat kontinuitas dari laporan yang adadengan laporan periode sebelumnya, sehingga merasa sulit untuk mengevaluasi perkembangan bisnisnya, sulitdalam menentukan strategi promosi dan prediksi situasi yang akan terjadi dimasa akan datang.

Rumusan masalah dari penelitian ini adalah "Bagaimanakah data warehouse yang dapat memenuhi kebutuhan pihak manajemen terhadap ringkasan informasi penerimaan mahasiswa baru agar bisa digunakan untuk penunjang dalam proses evaluasi, perencanaan serta pengambilan keputusan dalam strategi promosi STIE Binaniaga Bogor"

Penelitian ini mengkaji membuat platform data warehouse yang mampu menyajikan ringkasan informasi penerimaan mahasiswa baru secara utuh dari berbagai dimensi sesuai dengan kebutuhan bisnis yang ada, sehingga dapat membantu pihak manajemen STIE Binaniaga Bogor merumuskan permasalahan, memprediksi kondisi yang akan datang, melakukan evaluasi dan perencanaan serta mengambil keputusan strategis terhadap bentukpromosi yang efektif, dalam upaya meningatkan jumlah pendaftar mahasiswa baru.

Adapun batasan pembahasan dari penelitian adalah fokus pada pengembangan data warehouse dalam bentuk OnLine Analytical Processing (OLAP) dilengkapi dengan Business Intelligence untuk mendukung proses pengambilan keputusan di bidang penentuan arah promosi pihak manajemen.

Penggunaan data warehouse pada penerimaan mahasiswa baru STIE Binaniaga Bogor dapat memberikan ringkasan informasi yang cepat, utuh dan berkesinambungan sebagai penunjang bagi manajemen dalam melakukan evaluasi dan perencanaan terhadap perencanaan tertentu di bidang promosi bisnis, sehingga membantu manajemen dalam membuat keputusan yang tepat dan berkualitas. Manajemen STIE Binaniaga Bogor dapat menganalisa laporan penerimaan mahasiswa baru secara mandiri dengan memilih berbagai bentuk jenis laporan sesuai kebutuhan bisnis, berdasarkan data yang tersedia pada data warehouse.

\section{METODOLOGI PENELITIAN \\ Informasi Strategi}

Menurut Hanny Faristin (2005) informasi strategi merupakan rangkuman informasi transaksi sehari-hari guna suatu kepentingan, sehingga pihakpihak yang akan menggunakan informasi tersebut hanya tinggal melakukan pengamatan saja, karena informasi yang ditampilkan sudah berupa ringkasan dari keseluruhan data yang dibutuhkan. Bentuk informasi strategi adalah ringkasan informasi baik yang berasal dari lingkungan internal maupun ekternal organisasi, dan penggunanya adalah manajemen di tingkat puncak.

Ponniah (2001) menyatakan ada beberapa karakteristik yang harus dimiliki oleh sebuah sistem informasi strategi, sebagaimana dijelaskan dalam tabel berikut ini :

Tabel 1. Karakteristik Informasi Strategis

\begin{tabular}{|l|l|}
\hline Integreted & $\begin{array}{l}\text { Harus memiliki pandangan yang menyeluruh tentang } \\
\text { perusahaan }\end{array}$ \\
\hline $\begin{array}{l}\text { Data } \\
\text { Integritry }\end{array}$ & $\begin{array}{l}\text { Informasi yang disajikan harus akurat dan memenuhi aturan } \\
\text { serta proses bisnis perusahaan }\end{array}$ \\
\hline Accessible & $\begin{array}{l}\text { Informasi harus dapat diakses dengan mudah dan dapat } \\
\text { dianalisa }\end{array}$ \\
\hline Credible & $\begin{array}{l}\text { Setiap faktor terkait dengan kegiatan bisnis harus memiliki } \\
\text { tepat satu nilai }\end{array}$ \\
\hline Timely & $\begin{array}{l}\text { Informasi harus tersedia dalam time frame yang telah } \\
\text { ditentukan }\end{array}$ \\
\hline
\end{tabular}

Sumber: Ponniah (2001)

Sistem informasi yang ada seringkali kesulitan dan gagal menyediakan informasi strategi karena sumber data yang digunakan berasal dari sistem operasional sejak awal tidak dirancang untuk memenuhi kebutuhan penyediaan informasi strategi, tetapi untuk mendukung operasional kegiatan sehari-hari. Pengembangan model data warehouse menjadi solusi tepat bagi organisasi dalam menyediakan informasi strategi yang dapat digunakan oleh pimpinan puncak sebagi instrumen penunjang dalam melakukan analisa, evaluasi, perencanaan dan pengambilan keputusan strategi.

\section{Data Warehouse}

Data warehouse adalah kumpulan data yang berorientasi subjek, terintegrasi, memiliki dimensi waktu serta merupakan koleksi tetap (non-volatile) yang digunakan dalam mendukung proses pengambilan oleh para manajer tingkat puncak.

Data warehouse merupakan suatu database yang memiliki struktur khusus dalam pembuatan query dan analisis. Suatu data warehouse secara tipikal berisi data yang merepresentasikan sejarah bisnis dari sebuah perusahaan. Data tersebut dikumpulkan dari berbagai aplikasi yang ada, kemudian direstrukturisasi lagi dan disimpan dalam suatu Relational Database Management System (RDBMS).

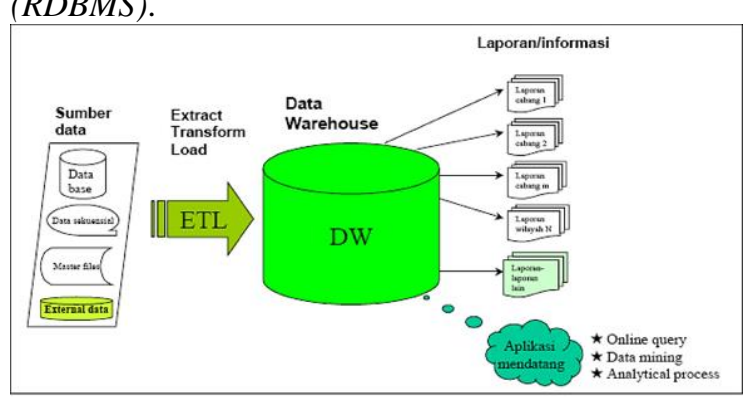

Sumber: Darmawikarta (2003)

Gambar 1. Proses Pembuatan Data Warehouse 
Berdasarkan gambar di atas diketahui bahwa sumber data warehouse berasal dari berbagai OnLine Transaction Processing (OLTP) database. Data yang terdapat dalam data warehouse merupakan hasil ekstraksi dari database operasional. Kemudian dengan query tertentu, data tersebut dimanfaatkan oleh Business IntelligenceApplication untuk menyajikan informasi strategi yang akan digunakan sebagai instrumen penunjang dalam proses evaluasi, perencanaan dan pengambilan keputusan strategi oleh pimpinan puncak.

Menurut Mallach dalam Puspitasari (2010), terdapat empat karakteristik dalam sebuah data warehouse, yaitu :

\section{Subject Oriented}

Suatu data warehouse dirancang untuk memenuhi kebutuhan analisis data berdasarkan subjek tertentu.

2. Integrated

Suatu data warehouse harus mampu mengintegrasikan data dari berbagai sumber sistem operasional yang beragam. Oleh karena itu sebelum data dari berbagai sumber yang berbeda ini disimpan ke dalam data warehouse maka harus menghilangkan inkosistensi data yang ada.

3. Non-volatile

Data transaksi yang sudah dimasukkan ke dalam data warehouse, tidak akan pernah diupdate atau dihapus (delete). Data yang tersimpan dalam data warehouse tidak dimaksudkan untuk aktifitas harian. Data dari sistem operasional dipindahkan ke dalam data warehouse dalam interval waktu tertentu disesuaikan dengan kebutuhan bisnis. Berikut ini adalah ilustrasi yang menggambarkan bahwa transaksi bisnis yang terjadi tidak mengupdate data di dalam data warehouse, namun mengupdate database sistem operasional :

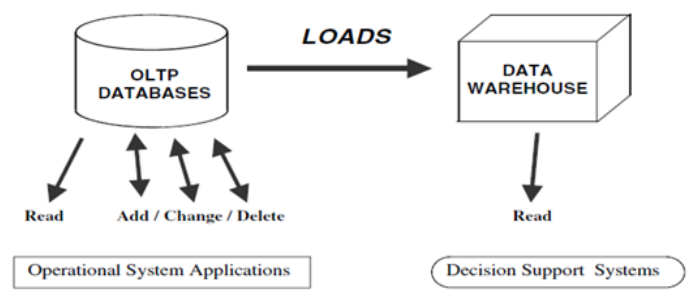

Sumber: Ponniah (2001)

Gambar 2. Perbedaan OLTP dan Data Warehouse

\section{Time Variant}

Data warehouse menyimpan sejarah (historical data). Waktu merupakan tipe atau bagian data yang sangat penting di dalam data warehouse. Di dalam data warehouse sering disimpan macammacam waktu, seperti waktu terjadinya transaksi, waktu suatu transaksi dirubah atau waktu transaksi dibatalkan, kapan suatu transaksi bisa efektif, kapan suatu transaksi masuk ke komputer, dan kapan suatu transaksi masuk ke data warehouse. Data warehouse dikatakan bernilai bagus jika data warehouse menyimpan sejarah.

Menurut Ponniah (2001) pada sebuah data warehouse terdapat lima komponen dasar yang berfungsi sebagai buildings blocks dari data warehouse itu sendiri, antara lain :

1. Sumber Data

Data yang berada dalam data warehouse bersumber dari komponen-komponen yang meliputi : data internal organisasi, data arsip, data distribusi dari sistem OLTP.

2. Data Staging

Data yang dikumpulkan dari berbagai sumber data perlu dilakukan perubahan, konversi dan dibuat format yang sesuai dengan keperluan query dan analisis. Ada tiga fungsi yang harus dilakukan untuk memperoleh kesiapan data, yakni ekstraksi, transformasi dan pemuatan data ke dalam storage data warehouse yang disebut dengan staging area.

3. DataStorage

Data warehouse memiliki repositori terpisah untuk penyimpanan datanya. Repositori data dimaksudkan untuk memelihara data warehouse dimaksudkan untuk memelihara data historis dengan volume yang besar untuk kebutuhan analisis, sehingga strukturnya juga disesuaikan untuk mendukung kebutuhan analisis. Data warehouse merupakan repositori data yang readonly karena penggunaan data warehouse dalam melakukan analisa memerlukan data stabil yang mencerminkan keadaan data dalam suatu periode waktu tertentu, sehingga data yang tersimpan dalam data warehouse juga dibuat dalam keadaan sedang tidak terupdate.

4. Information Delivery

Dalam menyediakan berbagai informasi yang berguna bagi komunitas pengguna yang beragam baik pengguna yang hanya mengandalkan report yang sudah disiapkan maupun pengguna yang mampu mengeksplorasi data untuk mendapatkan data untuk membuat query dan report sesuai kebutuhannya, komponen presentasi informasi mencakup berbagai metode penyampaian informasi. Metode ini mencakup ad hoc report yang disiapkan untuk siap pakai, query yang rumit, analisis multidimensional, analisis statistik, dan aplikasi data mining.

5. Metadata

Kamus atau katalog dari data yang berisi informasi mengenai data itu sendiri, misalnya struktur, informasi file, indeks, dan sebagainya. Tipe metadata dibagi menjadi tiga kategori, antara lain :

a. Operational Metadata 
Merupakan metadata yang terdiri dari semua informasi mengenai sumber data operasional, misalnya tipe data dan panjang field.

b. Extraction dan Transformation Metadata Merupakan informasi mengenai ekstraksi data, misalnya frekuensi ekstraksi, metode dan aturan bisnis untuk ekstraksi data. Metadata ini juga terdiri dari informasi mengenai transformasi data yang terjadi di staging area.

c. End User Metadata

Navigasi data warehouse yang akan memberikan petunjuk bagi end-user untuk menemukan informasi yang dicari.

Dimensi adalah perspektif atau entitas penting yang dimiliki oleh organisasi. Setiap dimensi mungkin memiliki satu tabel yang berasosiasi dengannya yang disebut dengan tabel dimensi yang mendeskripsikan tabel itu sendiri. Dimensi akan berubah jika analisis kebutuhan pengguna berubah. Dimensi mendefinisikan label yang membentuk isi laporan. Tabel dimensi berukuran lebih kecil dari pada tabel fakta dan berisi data tidak numerik. Pada data warehouse, kubus data merupakan kubus dengan n-dimensi (Han \& Kamber 2006).

Fakta adalah ukuran-ukuran numerik merupakan kuantitas yang akan dianalisis hubungan antar dimensinya. Tabel fakta berisi nama-nama fakta (ukuran) dan key dari tabel-tabel dimensi yang berelasi dengan tabel fakta itu. Data fakta diekstrak dari berbagai sumber. Data fakta cenderung stabil dan tidak berubah seiring waktu. Tabel fakta berukuran besar, memiliki jumlah baris sesuai dengan jumlah kombinasi nilai dimensi yang mungkin dan jumlah kolom sesuai dengan jumlah dimensi yang direpresentasikan (Han \& Kamber 2006).

Kubus data disebut juga cuboid, berasal dari banyak dimensi. Potongan cuboid yang lebih kecil dapat dibuat dengan mengambil sebagian dimensi dari sebuah cuboid besar. Potongan cuboid memiliki tingkat yang lebih tinggi (besar nilainya) dari cuboid asalnya, cuboid dengan tingkat terendah disebut cuboid (Han \& Kamber 2006).

Skema basis data berisi kumpulan enititas dan hubungan antarentitas. Sebuah data warehouse memerlukan skema yang ringkas dan berorientasi subjek yang dapat digunakan dalam analisis data online. Tipe-tipe skema model data multidimensi adalah (Han \& Kamber 2006).

\section{Skema Bintang (Star Schema)}

Skema ini disebut skema bintang karena hubungan antar tabel dimensi dan tabel fakta menyerupai bintang, dimana satu tabel fakta dihubungkan dengan beberapa tabel dimensi. Keuntungan yang didapat jika menggunakan skema ini adalah peningkatan kinerja data warehouse, pemrosesan query yang lebih efisien, dan waktu respon yang cepat.

2. Skema Snowflake (Snowflake Schema)

Skema snowflake adalah variasi dari skema bintang di mana beberapa tabel dimensi dinormalisasi. Sehingga dihasilkan beberapa tabel tambahan. Keuntungan yang didapat dengan menggunakan skema ini adalah penghematan memory, tapi waktu yang dibutuhkan untuk pemrosesan query menjadi lebih lama.

3. Skema Galaksi (Fact Constellation)

Pada skema galaksi beberapa tabel fakta berbagi tabel dimensi. Keuntungan menggunakan skema ini adalah menghemat memory dan mengurangi kesalahan yang mungkin terjadi.

Pembangunan Data warehouse dan On-Line Analytical Processing (OLAP) dibangun berdasarkan multi dimensional data model. Model ini memberikan kemudahan bagi pimpinan puncak dalam melakukan analisis terhadap informasi yang dihasilkan dari berbagai sudut pandang.Online Analytical Processing (OLAP) terdiri atas seperangkat tool untuk membantu proses analisis dan perbandingan data dalam database. Toosl serta metode OLAP membantu pengguna menganalisis data pada sebuah data warehouse dengan menyediakan berbagai tampilan data, dan didukung dengan representasi data grafik yang dinamis.

\section{Business Intelligence}

Menurut Rainardi dalam Suryanto (2012) BI adalah serangkaian kegiatan untuk memahami situasi bisnis dengan melakukan berbagai jenis analisis pada data yang dimiliki oleh organisasi serta data eksternal dari pihak ketiga untuk membantu menentukan strategi, keputusan bisnis yang taktis, dan operasional dan mengambil yang diperlukan tindakan untuk meningkatkan kinerja bisnis.

Menurut Langit (2007) Business Intelligence adalah metode untuk menyimpan dan penyajian data kunci perusahaan sehingga siapa pun di perusahaan dapat dengan cepat dan mudah meminta data yang akurat dan tepat waktu. $B I$ yang efektif memungkinkan pengguna akhir menggunakan data untuk memahami mengapa bisnis anda mendapatkan hasil tertentu, untuk memutuskan tindakan berdasarkan data masa lalu, dan akurat memprediksi hasil di masa mendatang.

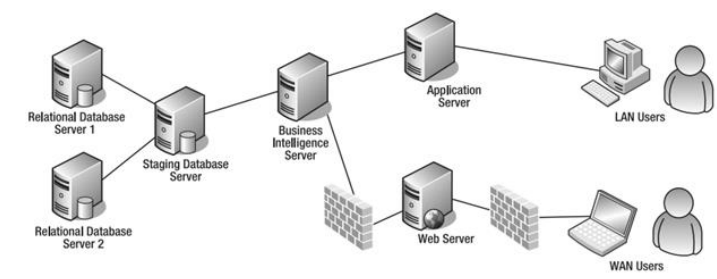

Sumber: Langit (2007)

Gambar 3. Enterprise BI Configuration 


\section{Tinjauan Studi}

Peneliti Suprapto Darudiato (2010) meneliti sistem informasi eksekutif dalam kegiatan yang berkaitan dengan penjualan produk di Cemerlang Skin. Penelitian membahas pengembangan data warehouse yang digunakan untuk pengambilan keputusan yang berkaitan dengan penjualan produk perusahaan, namun tidak menggambarkan trend penjualan secara periodik.

Peneliti Ariana Azimah dan Yudho Giri Sucahyo (2007) meneliti SIAK Universitas Nasional, Penelitian ini menghasilkan sebuah data warehouse beserta aplikasinya berbasis web yang digunakan untuk penyampaian informasi mengenai data akademik UNAS sebagai penunjang proses pengambilan keputusan, namun tidak menjelaskan proses ETL(Extract, Transform and Loading).

Peneliti Hanny Faristin (2005) meneliti SIAK Universitas Indonesia dengan mengusulkan pembuatan data warehouse yang meliputi perancangan technical infrastructure, technical infrastructure, user defined access, ETL design dan juga Unified Modelling Language, namun penelitian ini belum sampai pada tahap implementasi.

Peneliti Wahyu Dwi Suryanto (2012) meneliti dan merancang sebuat data warehouse data tracer study alumni IPB yang dikelola oleh Direktorat Pengembangan Karir dan Hubungan Alumni (DPKHA) IPB. Pada penelitian ini data yang dianalisis hanya data alumni yang memutuskan untuk bekerja saja, data alumni yang belum bekerja tidak termasuk didalamnya.

\section{Kerangka Pemikiran}

Berdasarkan permasalahan dan kebutuhan yang telah dijelaskan terbentuklah kerangka pemikiran yang menjadi dasar dari penelitian.

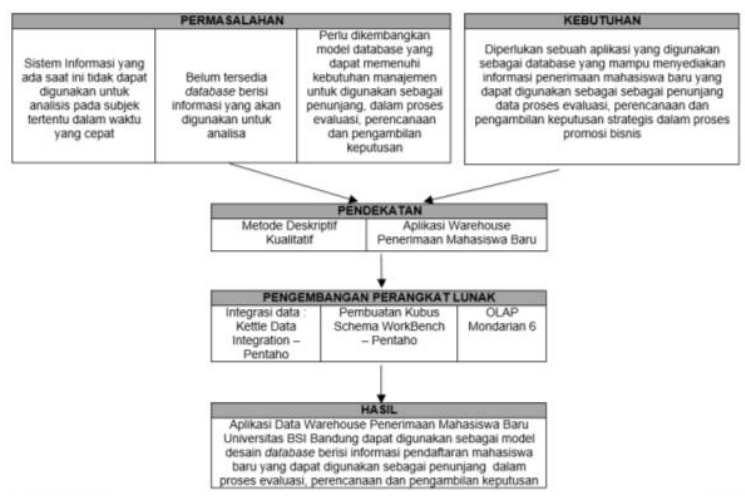

Sumber: Hasil penelitian penulis (2019)

Gambar 4. Kerangka Pemikiran Perancangan Data Warehouse Penerimaan Mahasiswa Baru

\section{Jenis Penelitian}

Penelitian tentang pengembangan data warehouse Penerimaan Mahasiswa Baru STIE
Binaniaga Bogor menggunakan pendekatan deskriptif kualitatif. Menurut Moh. Nazir (2002), metode deskriptif adalah suatu metode dalam meneliti status sekelompok manusia, suatu objek, suatu set kondisi, suatu sistem pemikiran ataupun suatu kelas peristiwa pada masa sekarang. Tujuan dari penelitian deskriptif adalah untuk membuat gambaran secara sistematis, faktual dan akurat mengenai fakta, sifat serta hubungan antar fenomena yang diteliti. Dalam pengumpulan datanya digunakan teknik wawancara, dengan schedule questionair ataupun interview guide. Menurut Moleong (2005), metode kualitatif adalah suatu metode penelitian yang dimaksudkan untuk memahami fenomena tentang apa yang dialami oleh subjek penelitian, misalnya perilaku, persepsi, motivasi, tindakan dan lain-lain secara holistik, dan dideskripsikan dalam bentuk kata - kata dan bahasa pada suatu konteks khusus yang alamiah dengan memanfaatkan berbagai metode alamiah.

Data yang digunakan dalam penelitian ini berasal dari data primer dan data sekunder. Pengumpulan data primer dilakukan dengan observasi lapangan dan wawancara. Sedangkan pengumpulan data sekunder didapatkan dari studi pustaka melalui studi literatur, tulisan ilmiah tentang data warehouse dan studi banding.

\section{Analisis Data dan Interpretasi}

Berapa tahapan analisis data dan interpretasi yang dilakukan dalam penelitian pengembangan data warehouse penerimaan mahasiswa barudengan pendekatan deskriptif kualitatif adalah :

1. Identifikasi subjek area

Tahapan ini dilakukan untuk mengetahui kebutuhan pengguna terhadap aplikasi yang akan dikembangkan. Kegiatan yang dilakukan adalah :

a. Observasi untuk meneliti sistem berjalan dan merumuskan permasalahan yang terjadi dari sistem yang ada.

b. Studi pustaka untuk memahami konsep dasar dan teori yang mendukung penelitian.

c. Menganalisa dokumen-dokumen yang ada pada sistem yang sedang berjalan.

d. Melakukan wawancara kepada beberapa stakeholders terkait.

2. Membuat rancangan data warehouse

a. Perancangan arsitektur data warehouse

Terdiri dari Perancangan logical dan physical data warehouse. Kegiatan yang melakukan proses mengumpulkan data source sampai terbentuknya data warehouse.

b. Perencanaan sumber data

Sumber data diperoleh dari database Penerimaan mahasiswa baru yang ada di database online pmb. Seluruh data tersebut harus melalui proses ETL (Extract, Transform and Loading) pada staging area sebelum masuk ke dalam data warehouse. 
c. Pemodelan data dimensional

Penentuan model data dimensional dengan melakukan proses identifikasi ukuran dan fakta-fakta tabel yang akan digunakan, berikutnya menentukan dimension untuk semua informasi yang dibutuhkan manajemen untuk dijadikan sebagai parameter atau sudut pandang terhadap measure sehingga dapat mendefinisikan suatu transaksi dalam pembuatan data warehouse penerimaan mahasiswa baru.

3. Implementasi data warehouse

a. Membuat prototype data warehouse dan aplikasi presentasinya.

1) Penyiapan hardware dan instalasi software.

2) Melakukan proses ETL(Extract, Transform and Loading)

b. Membersihkan data yang ada di sumber database.

c. Mengubah bentuk data dari sumber data yang berbeda agar mempunyai format yang sama.

d. Memasukan data yang sudah bersih dari sumber database ke dalam data warehouse

e. Menentukan bisnis area dan dimensi informasi yang akan ditampilkan.

4. Pengujian dan analisis data warehouse

a. Melakukan uji coba cara penggunaan dan manfaat dari data warehouse yang telah dibuat, apakah telah sesuai dengan user requirement.

b. Melakukan analisa dan pendeteksian kelemahan dari data warehouse berdasarkan dari uji coba yang telah dilakukan

5. Evaluasi

Pada tahap ini melakukan pengujian dengan pengguna data warehouse dan meminta saran dari pengguna untuk penyempurnaan data warehouse dengan cara pengisian questioner oleh pengguna.

\section{HASIL DAN PEMBAHASAN}

\section{Identifikasi Subjek Area}

Dalam pengembangan data warehouse perlu diperhatikan hal-hal yang menjadi permasalahan yang dihadapi dan kebutuhan dari pengguna yang akan memanfaatkan infromasi strategi yang dihasilkan dari data warehouse. Maka inilah yang akan menjadi subjek area pembahasan dan pembangunan aplikasi data warehouse.

\subsection{Observasi Permasalahan}

Permasalahan pada sistem informasi yang ada saat ini,berdasarkan dari hasil observasi yang ditemukan, yaitu laporan rutin dan periodik yang berasal dari database operasional belum bisa memenuhi kebutuhan akan informasi yang ringkas, belum komprehensif dan belum berkesinambungan dengan laporan yangsudah pernah dilaporkan pada periode sebelumnya. Sehingga perlu adanya pengolahan kembali laporan jika pimpinan puncak bermaksud untuk melakukan analisa terhadap informasi yang telah diberikan.

Dari hasil analisa yang dilakukan, terdapat kebutuhan fungsional yang harus dipenuhi antara lain :

1. Data Warehouse harus mampu melakukan analisa terhadap data mahasiswa baru yang mendaftar yang meliputi analisa jurusan mana yang paling banyak diminati dan yang kurang diminati, gelombang pendaftaran mana yang paling banyak mendaftar,status beasiswa,sekolah asaldan mengelompokkan data pendaftaran mahasiswa tersebut berdasarkan kategori tertentu dan dalam periode tertentu.

2. Data warehouse harus mampu melakukan analisa data penerimaan mahasiswasecara berkesinambunganyang terkait data periode telah lalu, dengan memberikan hasil perbedaan atau perbandingan, serta sebagai bahan acuan evaluasi dari masing-masing priode.

Dari hasil analisa yang dilakukan juga, terdapat kebutuhan non fungsional yang harus dipenuhi, antara lain :

1. Informasi strategi dalam data warehouse hanya dapat diakses melalui jaringan institusi.

2. Hanya pengguna yang mempunyai akun user dan password saja, yang diizinkan untuk dapat mengakses informasi strategi dalam data warehouse.

3. Jikaterjadi kegagalan dalam proses ETLdikarenakan ada masalah di sumber data, maka data yang ada dalam data warehouse tidak boleh rusak.

4. Waktu respon maksimum30 detik untuk setiap permintaan laporan atau melihat $O L A P$.

\subsection{Analisa Dokumen}

Penulis melakukan analisa terhadap aplikasi sistem informasi penerimaan mahasiswa baru online milik STIE Binaniaga Bogor serta dokumendokumen laporan yang dikeluarkan darinya guna mengetahui bentuk laporan transaksional yang sudah ada sebagai bahan masukan bagi penulis dalam merancang data warehouse penerimaan mahasiswa baru.

\subsection{Wawancara}

Penulis melakukan wawancara dengan bagianbagian terkait seperti Divisi Informasi Publik, dan Biro teknologi Informasi, guna mengetahui detail bisnis proses yang berjalan di sistem informasi penerimaan mahasiswa baru, sehingga penulis memperoleh informasi yang jelas database dan tabel apa saja yang akan diambil sebagai sumber data bagi data warehouse penerimaan mahasiswa baru.

Perancangan Data Warehouse Untuk Informasi Strategi Studi Kasus Penerimaan Siswa Baru STIE Binaniaga Bogor 


\section{Perancangan Data Warehouse}

Kegiatan-kegiatan yang dilakukan dalam perancangan datawarehouse, antara lain :

a. Perancangan Arsitektur Data Warehouse Pada perancangan data warehouse ini sumber data yang dipakai adalah data PMB online yang ada di Divisi Informasi Publik (DIP).Berikut adalah rancangan arsitektur logical dan arsitektur physical data warehouse :

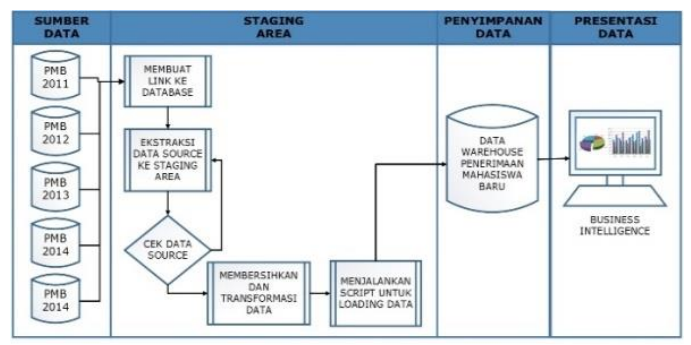

Sumber: Hasil penelitian penulis (2019)

Gambar 5. Rancangan Arsitektur Logik Data Warehouse

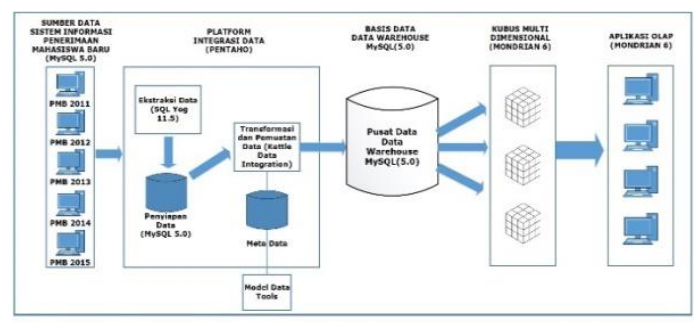

Gambar 7. Rancanga Arsitektur Fisik Data Warehouse Penerimaan Mahasiswa Baru

Sumber: Hasil penelitian penulis (2019)

Gambar 6. Rancangan Arsitektur Fisik Data Warehouse

Di dalam perancangan data warehouse ini, user mengakses data warehouse melalui server aplikasi. Data warehouse dan server aplikasi direncanakan berada pada mesin yang sama. Database sumber dan data warehouse menggunakan RDBMS Mysql Server 5.0.

Data yang akan digunakan untuk analisis didapat dari database operasional PMB Online. Pada data tersebut dilakukan proses ekstraksi, pembersihan, transformasi dan pemuatan data untuk dipindahkan ke dalam database data warehouse. Data yang telah dipindahkan ke dalam basis data data warehouse dirancang beberapa kubus yang akan digunakan untuk analisis data PMB berdasarkan kubus-kubus yang terbentuk. Pimpinan dapat melakukan analisis terhadap informasi dari berbagai dimensi yang berbedabeda. Untuk memudahkan melakukan analisis dibangun sebuah aplikasi OLAP dengan menggunakan Tools Mondrian 6.

b. Perencanaan Sumber Data Warehouse

Dalam menunjang pelaksanaan kegiatan pelayanan akademis, STIE Binaniaga telah memiliki website penerimaan mahasiswa baru (PMB) untuk pendaftaran calon mahasiswa baru yang ingin kuliah serta mencatat semua informasi yang dimilikicalon mahasiswa yang mendaftar di STIE Binaniaga Bogor. Sumber data yang akan digunakan untuk warehouse adalah data yang diperoleh dari data operasional PMB, tidak semua tabel yang ada pada database tersebut digunakan sebagai sumber data warehouse.

c. Pemodelan Data Dimensional

Skema yang digunakan untuk pemodelan adalah star schema/skema bintang yang terdapat satu tabel fakta dan beberapa tabel dimensi. Alasan penggunaan skema bintang ini adalah proses query lebih ringan dan memudahkan penjelajahan terhadap data dimensinya, selain itu tabel dimensinya tidak memerlukan tabel sub dimensi karena tabel dimensinya tidak mengandung ringkasan atau tidak memiliki perbedaan tingkat urutan.

Berikut ini merupakan gambar Entity Relationship Diagram (ERD) pada data warehouse penerimaan mahasiswa baru.

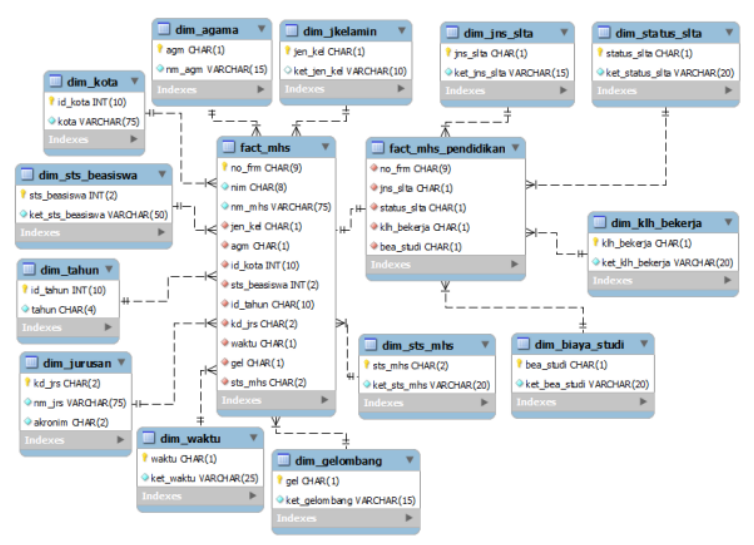

Sumber: Hasil penelitian penulis (2019)

Gambar 7. Diagram ERD Data Warehouse Penerimaan Mahasiswa Baru

\subsection{Implementasi Data Warehouse Penyiapan Hardware dan InstalasiSoftware}

Berikut ini adalah perangkat keras yang digunakan dan perangkat lunak yang diinstall dalam pembuatan prototype dan aplikasi presentasi data warehouse penerimaan mahasiswa baru :

1. Hardware : Processor Intel $\left(\right.$ Core $\mathrm{TM}_{\mathrm{i}} 5$ 3317UCPU@ $1.70 \mathrm{GHz}$, Memory 4 GB dan Harddisk 2TB. 
2. Software : Microsoft Windows 8, MySQL 5.0, SQL Yog Enterprise 11.5, MySQL Workbench 5.2 CE, Pentaho Data Integration 4.1.0, Pentaho Schema Workbench 3.2.1.13885, Pentaho Mondrian 3.2.1.13885, Apache Tomcat 7.0.6, Photoshop CS4, Notepad++ v6.8.3, Google Chrome 46.0.2490.86 m.

\subsection{Membuat Prototype Data Warehouse dan Aplikasi Presentasinya}

Pembuatan prototype data warehouse dimaksudkan untuk mengetahui sejauh mana kesesuaian antara kebutuhan user dan Data warehouse yang dibuat. Prototype ini akan dijadikan sebagai gambaran umum untuk merepresentasikan model data warehouse yang dibuat. Kegiatan itu meliputi :

a. Penyediaan Informasi

Pembangunan data warehouse diharapkan mampu memenuhi kebutuhan informasi yang cepat, tepat dan akurat, sehingga kegiatan evaluasi, perencanaan dan pengambilan keputusan untuk keperluan promosi kampus dapat berjalan dengan baik.

b. Presentasi Data Warehouse

Pemanfaatan tools dalam presentasi data perlu dipertimbangkan beberapa hal meliputi fitur yang ada, biaya saat melakukan development dan maintainance setelah data warehouse beroperasi. Untuk presentasi data, platform database yang digunakan untuk data warehouse ini adalah MySQL 5.0, sedangkan tools yang digunakan untuk menyampaikan informasi kepada pengguna adalah tools yang dapat berintegrasi dengan MySQL sebagai platform database data warehouse, yaitu Mondrian.

Selain Mondrian, tools yang digunakan untuk menyampaikan informasi kepada pengguna adalah JPivot yang merupakan JSP yang dapat menampilkan OLAP table dan chart. JPivot mempunyai kemampuan navigasi OLAP seperti drill down, Slice and Dice.

Sedangkan untuk media yang digunakan untuk mempresentasikan data adalah berupa web browser (Firefox, Opera, Chrome, dll) yang aplikasinya berbasis web dengan bahasa pemrograman java.

\subsection{Proses Extract, Transform and Loading Data}

Proses penting dalam pengoperasian data warehouse Penerimaan Mahasiswa Baru STIE Binaniaga Bogor adalah proses Extraction, Transformation and Loading. Proses ETL dataPMB dieksekusi dengan menggunakan program aplikasi berbasis Java yang disebut "Kettle Data Integration". Berikut ini adalah contoh rancangan integrasi data dan proses ETL padaPMB STIE
Binaniaga Bogor dalam mempopulasikan Tabel fact_mahasiswa

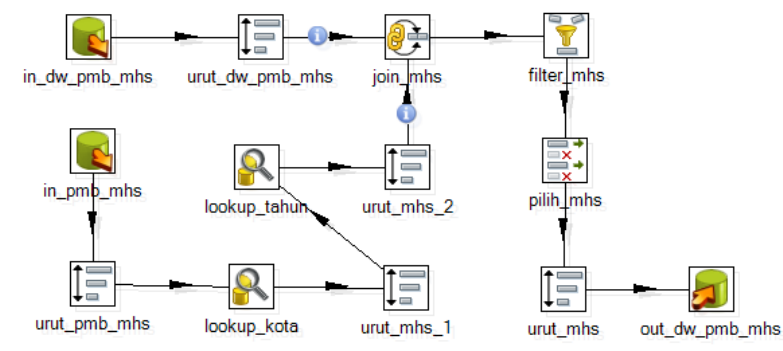

Sumber: Hasil penelitian penulis (2019)

Gambar 8. Proses populasi tabel fact_mahasiswa

Pada tabel fact_mahasiswa ditentukan elemen data yang akan menjadi dimensi yaitu : kota, tahun, dan kategori mahasiswa.

\subsection{Pengujian dan Analisis Data Warehouse}

Proses uji coba awal terhadap data warehouse dimulai dengan pengujian dari data warehouse itu sendiri dan prototype interface dari data warehouse.

1. Pengujian data dari data warehouse.

Pengujian dilakukan dengan menggunakan query dari data pmb terhadap data yang ada di database data warehouse menggunakan perangkat SQL Yog Enterprise dengan memperhatikan mapping kolom dan tabel yang tersedia.

Berikut adalah data calon mahasiswa yang mendaftar dalam database pmb_student yang merupakan sumber data (OLTP) dan data fact_mahasiswa dalam database dw_pmb yang menjadi data warehouse (OLAP) sebagaimana gambar di bawah ini :

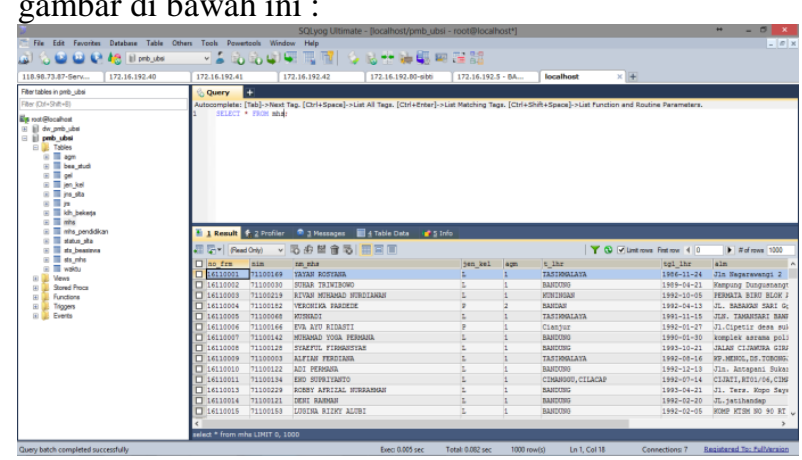

Sumber: Hasil penelitian penulis (2019)

Gambar 9. Tampilan Data mahasiswa dengan SQL Yog Enterprise 


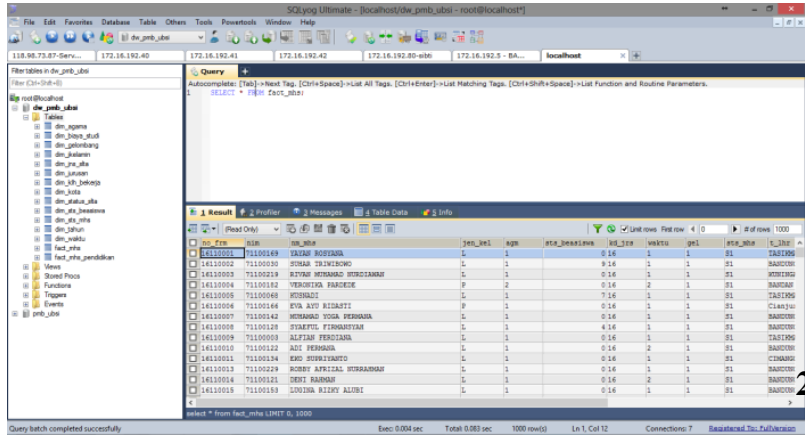

Sumber: Hasil penelitian penulis (2019)

Gambar 10. Tampilan Data fact_mahasiswa dengan SQL Yog Enterprise.

Berdasarkan dari hasil ujicoba dengan perangkat SQL Yog Enterprise menunjukan adanya konsistensi, karena tidak terdapat perbedaan antara data sumber (OLTP) dengan data warehouse (OLAP).

2. Pengujian prototype interface data warehouse oleh pejabat yang akan menjadi pengguna data warehouse. Pada pengujian ini diundang responden yang merupakan ahli di bidang masing - masing yang diharapkan mampu memberikan validasi ahli (Expert Judgement) terhadap data warehouse Penerimaan Mahasiswa Baru.

Hal - hal yang digunakan sebagai acuan dalam uji coba prototype interface adalah :

a. Tingkat user friendly dalam penggunaan aplikasi.

b. Tingkat kemudahan menjalankan aplikasi

c. Tingkat respon yang diberikan aplikasi dalam setiap action dari user.

d. Kemampuan data warehouse dalam merepresentasikan informasi yang dibutuhkan dalam pengambilan keputusan strategi, seperti :

1) Informasi tentang data calon mahasiswa yang mendaftar, ditujukan untuk berbagai pihak yang mendukung proses evaluasi dan perencanaan kegiatan promosi tentang apa saja yang perlu dimaksimalkan oleh pihak manajemen untuk meningkatkan jumlah calon mahasiswa yang mendaftar kuliah di STIE Binaniaga Bogor.

2) Informasi tentang trend peminatan jurusan pendaftaran calon mahasiswa baru berdasarkan background sekolah asal atau pun dari informasi data diri calon mahasiswa.

e. Kemudahan yang disediakan oleh data warehouse dalam membantu untuk menganalisa data dari berbagai sudut pandang. f. Kemampuan aplikasi untuk menganalisa data sebagai bahan pertimbangan dalam proses pengambilan keputusan strategi.

g. Kemampuan data warehouse dalam menghasilkan informasi yang dapat mewakili kelengkapan data dan mewakili kebutuhan informasi lembaga, khususnya untuk keperluan promosi.

\subsection{Evaluasi}

Dari hasil evaluasi awal ditemukan beberapa kelemahan dari data warehouse dan interface prototype, antara lain :

1. Dalam Proses ETL dari data sumber ke data warehouse, masih membutuhkan bantuan database administrator untuk merapikan data pada field-field tertentu akibat tidak cermat atau tidak konsistennya calon mahasiswa yang mendaftar / memasukan data diri diwebsite Penerimaan Mahasiswa Baru.

2. Dengan waktu penelitian yang terbatas, data warehouse belum mampu membuat prediksi informasi selanjutnya, hanya sebagai informasi penunjang yang dibutuhkan untuk keperluan kegiatan promosi.

\subsection{Perubahan Yang Diharapkan}

Dengan penggunaan data warehouse, proses pembuatan laporan yang komprehensif dan berkesinambungan tentang informasi penerimaan mahasiswa baru dapat dilakukan dengan cepat dan efektif, karena tidak diperlukan lagi pembuatan query baru atau mengolahnya secara manual dengan aplikasi spreadsheet.

Data warehouse memungkinkan pembuatan laporan dari berbagai dimensi yang ada. Proses OLAP data warehouse yang terpisah dengan proses OLTP tidak akan mengganggu aktifitas operasional data Penerimaan Mahasiswa Baru yang sedang berjalan.

\subsection{Implikasi Penelitian}

Penggunaan data warehouse dalam menyajikan informasi strategi bagi manajemen menjadi sebuah sistem dan prosedural baru dalam organisasi yang membuat pimpinan selaku pengguna sistem informasi ini harus bisa dan terbiasa memanfaatkan fasilitas tersebut.

Dengan penggunaan data warehouse diharapkan seluruh data yang tidak konsisten akibat sistem informasi Penerimaan Mahasiswa Baru yang belum sempurna atau kesalahan calon mahasiswa dalam mengisi data saat melakukan entry data ke dalam website PMB dapat diidentifikasi dengan cepat dan diperbaiki, sehingga akan memudahkan proses Extract, Transform and Loading dari data sumber ke data warehouse dan menyederhanakan proses pembuatan pelaporan dan analisis.

\subsection{Penelitian Lanjutan}


Hasil penelitian ini juga dapat digunakan sebagai bahan referensi untuk penelitian selanjutnya, seperti penerapan data mining yang dapat dimanfaatkan untuk mencari pola karakteristik untuk keperluan penentuan jenis promosi yang tepat, serta evaluasi keberhasilan suatu pelayan akademik dan pembuatan prediksi perkiraan jumlah calon mahasiswa yang mendaftar perpriodiknya.

\section{KESIMPULAN}

Berdasarkan hasil penelitian yang telah dilakukan, maka dapat disimpulkan bahwa pengembangan data warehouse Penerimaan Mahasiswa Baru pada STIE Binaniaga Bogor telah mampu melakukan ekstraksi data operasional dari sistem informasi Penerimaan Mahasiswa Baru menjadi ringkasan informasi strategis yang berguna bagi manajemen STIE Binaniaga sebagai informasi penunjang dalam melakukan analisa, evaluasi, perencanaan dan pengambilan keputusan di bidang pelayanan akademik.

Penggunaan data warehouse memberikan kemandirian dan kemudahan bagi manajemen dalam memilih bentuk laporan yang diinginkan sesuai informasi yang tersedia. Informasi data warehouse dapat disajikan dengan berbagai dimensi sesuai kebutuhan, karena data warehouse mempunyai kemampuan untuk roll up dan drill down, mampu melakukan query dengan cepat, dan mampu menampilkan data dengan baik dalam bentuk tabular maupun grafik. Dengan tersedianya data warehouse, manajemen dapat memperoleh informasi yang memungkinkan untuk melakukan analisis lebih jauh terhadap subjek - subjek tertentu yang dikehendaki dalam waktu yang lebih cepat.

\section{REFERENSI}

Azimah, Ariana \& Sucahyo, Yudho G. (2007). Penggunaan Data Warehouse dan Data Mining Untuk Data Akademik Sebuah Studi Kasus Pada Universitas Nasional. Jurnal Sistem Informasi MTI UI Vol.3No.2 Oktober 2007. http://repository.ui.ac.id/contents/koleksi/1 $\underline{1 / 22 . p d f}$

Darmawikarta, Djoni (2003). Mengenal Data Warehouse, Tip \& Trik ilmukomputer.com.

Darudiato, Suparto. (2010). Perancangan Data Warehouse Penjualan Untuk Mendukung Kebutuhan Informasi Eksekutif Cemerlang Skin Care. [OnLine]. http://repository.upnyk.ac.id/36/1/E-

43_PERANCANGAN_DATA_WAREHO

USE_PENJUALAN_UNTUK_MENDUK

UNG_KEBUTUHAN_INFORMASI_EKS

EKUTIF_CEMERLANG.pdf
Faristin, Hanny. (2005). Perancangan data warehouse untuk kegiatan akademik di Universitas Indonesia. Fakultas Ilmu Komputer. Universitas Indonesia.

Gustiarahman, Irfan. (2006). Data Warehouse. April, 28, 2011. http://myhut.org/public/datawarehouse.doc.

Han J, Kamber M. 2006. Data Mining:Concepts and Techniques. San Francisco: Morgan Kaufmann Publisher.

Langit, Lynn. (2007). Foundations of SQL Server 2005 Business Intelligence. New York : Apress.

Mallach, Efrem. G. (2000). Decision Support and Data Warehouse Systems. New York: McGraw-Hill.

Nugroho, Adi. (2004). Konsep Pengembangan Sistem Basis Data. Bandung: Penerbit Informatika.

Ponniah, Paulraj (2001). Data Warehousing Fundamentals A Comprehensive Guide For IT Proffesionals. New York: WileyInterscience.

Rainardi V. 2010.Building a Data warehouse With Examples in SQL Server. New York. Apress.

Suryanto, Wahyu Dwi (2012). Pengembangan Data Warehouse Dan Aplikasi OLAP Data Tracer Study Alumni IPB Berbasis Web Menggunakan Microsoft Business Intelligence.

http://wdwisuryanto.staff.ipb.ac.id/files/201 2/01/Makalah_Praseminar1.pdf 